\title{
Pensonomonoor
}

2015, vol. 74, 95-108

http://dx.doi.org/10.12657/denbio.074.010

\author{
Wojciech Szewczyk, Hanna Kwaśna, Jolanta Behnke-Borowczyk
}

\section{Populations of Armillaria species in pine plantations in west-central Poland}

Received: 30 November 2014; Accepted: 9 April 2015

\begin{abstract}
Two diploid isolates of Armillaria gallica and 143 diploid isolates of A. solidipes were obtained from 145 samples of rhizomorphs, fruit bodies and infected wood of sessile oak and Scots pines from 5-10-year-old Scots pine plantations in three Forest Districts located 100-350 km apart in west-central Poland. Based on pairings among the 145 isolates, 18 somatic compatibility groups (genets) of $A$. solidipes were distinguished in the three plantations. Sequencing of ITS1/2 rDNA of 18 isolates representing the 18 genets delineated four nuclear haplotypes. This suggests that many of the $A$. solidipes genets are closely related and were possibly established by sib-related basidiospores. With a few exceptions there was general geographical specialization of genets but not haplotypes. Geographical specialization of genets and the dominance of single haplotypes suggest that the $A$. solidipes population results from clonal rather than sexual reproduction. Sequencing of the ITS1/2 and IGS-1 rDNA showed small nucleotide diversity in ITS1/2 rDNA and much more diversity in IGS-1 rDNA of the isolates of $A$. solidipes studied. However, none of these regions has sufficient resolution for the clear differentiation of $A$. solidipes from $A$. borealis. The sequences of the EF 1-alpha gene showed high interspecific variability in Armillaria species and very low intraspecific variability in $A$. solidipes. This gene is the most appropriate for reliable identification of biological species and subgroups of Armillaria. Its application is the most useful in ecological and epidemiological studies of Armillaria.
\end{abstract}

Additional key words: Armillaria solidipes, EF-1 alpha gene, IGS, ITS, somatic incompatibility, population structure

Addresses: W. Szewczyk, H. Kwaśna, J. Behnke-Borowczyk, Department of Forest Pathology, Faculty of Forestry, Poznań University of Life Sciences, Wojska Polskiego 71c, 60-625 Poznań, Poland, e-mail: kwasna@up.poznan.pl

\section{Introduction}

Armillaria root rot represents one of the most dangerous diseases of the root systems of pine and other trees in the Northern and Southern Hemispheres. In forestry it causes reduction of tree growth, tree mortality and predisposition to windthrow, which decreases commercial timber production. In Poland in 2012 the pathogen was found to occur with high incidence on 99215 ha (Małecka et al. 2014).

At present over 40 species of Armillaria have been described (Volk and Burdsall 1995; Pegler 2000). Seven species, including $A$. borealis Marxm. et Korhonen, A. cepistipes Velen, A. ectypa (Fr.) Lamoure, A. gallica Marxm., A. mellea (Vahl: Fr.) Kumm., A. solidipes (Peck) and A. tabescens (Scop.: Fr.) Emel., occur in Eu- 
rope (Korhonen 1995). Only A. ectypa has not been reported from Poland (Szewczyk and Mańka 2002; Szewczyk and Łakomy 2011; Żółciak 1999b, 2005).

Armillaria solidipes and A. gallica are the most dangerous in forests. They dominate in fresh mixed coniferous and broadleaved forest, particularly on younger trees (Korhonen 1978; Rishbeth 1985; Hood et al. 1991; Morrison et al. 1991; Żółciak 1999b; Szewczyk and Mańka 2002). The relative importance of $A$. solidipes increases when conifers replace hardwoods (Guillaumin et al. 1993; Legrand and Guillaumin 1993). The presence of Armillaria depends on the decomposition of woody substrata and absorptive activities of its mycelium. Mycelium in wood fuels the foraging activities of rhizomorphs which grow in the soil and epiphytically along roots.

Previously identification of Armillaria based on characters of its fruit bodies in situ and mycelium and rhizomorphs in vitro proved not to be efficient because of limited morphological variation. Furthermore fruit bodies are short-lived and could be examined only seasonally. Somatic incompatibility tests performed by pairing haploid tester strains with the isolates in question (Korhonen 1978) were time-consuming, and sometimes ambiguous and difficult to interpret. The reaction tends to be indistinct in diploid-haploid pairings (Guillaumin et al. 1991), and field isolates established from mycelial mats, rhizomorphs and decayed wood are usually diploid (Hintikka 1973).

Other methods for Armillaria identification have used immunology (Lung-Escarmant et al. 1985) or analysis of isoenzyme polymorphism (Morrison et al.1985; Mwenje and Ride 1997). All of them were quickly replaced by faster and more reliable molecular techniques, e.g. AFLP, RAPD, RFLP and sequencing (Smith and Anderson 1989; Coetzee et al. 2000; Kim et al. 2000; Dettman and Kamp 2001; Pildain et al. 2009; Wingfield et al. 2009).

Sequencing conventionally targets conserved regions of the ribosomal RNA gene (rDNA), i.e. the internal transcribed spacer (ITS) and intergenic spacer (IGS) (Anderson and Stasovski 1992; Harrington and Wingfield 1995; Banik et al. 1996; Chillali et al. 1998 a, b; Terashima et al. 1998a,b; Pérez-Sierra et al. 1999; Fukuda et al. 2003; Lochman et al. 2004a; Matsushita and Suzuki 2005; Schnabel et al. 2005; Keča et al. 2006; Sekizaki et al. 2008). More recently the translation elongation factor-1 alpha (EF-1 alpha) gene, which encodes an essential part of the protein translation machinery, was shown to have high phylogenetic utility and has been used in studies on fungi. Therefore this gene has been used in studies to establish phylogenetic relationships among Armillaria species from the Northern and Southern hemispheres (Maphosa et al. 2006), to elucidate the relationship between two closely related species, $A$. gallica and A. cepistipes (Antonin et al. 2009), and for identification of species of Armillaria in Japan (Hasegawa et al. 2010).

The objectives of the present research were: (i) to investigate the population structure of Armillaria in Scots pine plantations in Poland and (ii) to compare the effectiveness of somatic incompatibility test, and RFLP and sequencing of the ITS1/2, IGS- 1 rDNA and EF-1 alpha gene for reliable identification of different species of Armillaria. We hypothesized that Scots pine plantations in west-central Poland are colonized by a few species of Armillaria and different haplotypes of $A$. solidipes and that there would be geographical specialization in the distribution of Armillaria species and haplotypes.

\section{Materials and Methods}

\section{Isolates}

Isolates of Armillaria were obtained from severely diseased, 5-10-year-old Scots pine (Pinus sylvestris L.) plantations in three Forest Districts located 100$350 \mathrm{~km}$ apart in west-central Poland, in 2005-2008 (Fig. 1, Table 1). The Forest Districts were Siemianice $\left(51.32083^{\circ} \mathrm{N} 16.91000^{\circ} \mathrm{E}\right)$, Zielonka $\left(52.5533^{\circ} \mathrm{N}\right.$ $\left.17.1133^{\circ} \mathrm{E}\right)$ and Złotów $\left(53.36346^{\circ} \mathrm{N} 17.04082^{\circ} \mathrm{E}\right)$. Two infection centres were chosen randomly in each plantation. The infection centres were surrounded by areas with no symptoms of disease. Four plots were located randomly in each infection centre. Each plot was 0.5 ha, established by marking a 40 -m-long radius from the plot's centre. The area sampled in each location, summed from eight plots, was 4 ha.

Diseased and dead trees were found in each plot. Symptoms of infection included chlorotic needles, dieback of twigs, a layer of resin, debris and fungal

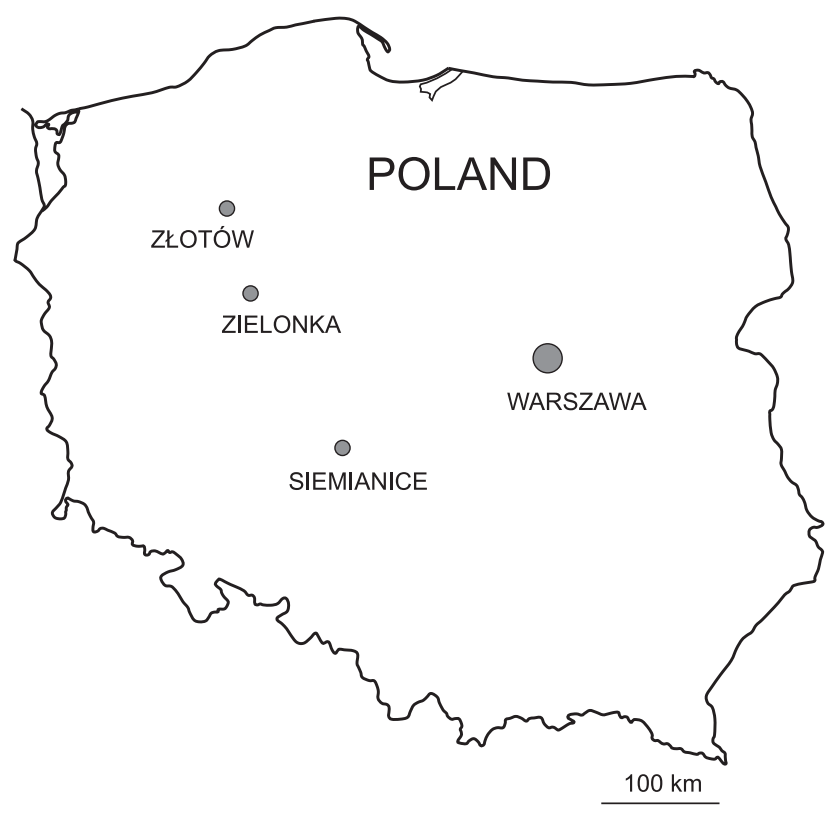

Fig. 1. Location of Scots pine plantations surveyed in Poland 
Table 1. Representative Armillaria isolates used in this study

\begin{tabular}{|c|c|c|c|c|c|c|c|c|}
\hline \multirow[b]{2}{*}{ Species } & \multirow{2}{*}{$\begin{array}{l}\text { Genet } \\
\text { based on somatic } \\
\text { compatibility test }\end{array}$} & \multicolumn{3}{|c|}{ RFLP of IGS-1 rDNA pattern with enzyme } & \multirow{2}{*}{$\begin{array}{l}\text { Haplotype } \\
\text { based on } \\
\text { sequencing } \\
\text { of ITS1/2 } \\
\text { rDNA }\end{array}$} & \multirow[b]{2}{*}{ Origin } & \multirow[b]{2}{*}{ Substrate } & \multirow[b]{2}{*}{ Location } \\
\hline & & AluI & BsmI & TaqI & & & & \\
\hline A. gallica & $7023^{a}$ & $400240180^{1}$ & & $345190160^{1}$ & & Quercus petraea & Fruit body & Siemianice \\
\hline \multirow[t]{18}{*}{ A. solidipes } & $6001^{b}$ & $300200150^{2}$ & $590290^{1}$ & $345230150^{2}$ & I & Pinus sylvestris & Infected wood & Zielonka \\
\hline & $2603^{c}$ & 300200150 & 590290 & 345230150 & I & Soil surface & Rhizomorph & Zielonka \\
\hline & $\underline{6036}$ & 300200150 & 590290 & 345230150 & I & Soil surface & Rhizomorph & Złotów \\
\hline & $\underline{6051^{\mathrm{d}}}$ & 300200150 & 590290 & 345230150 & I & P. sylvestris & Infected wood & Złotów \\
\hline & $6095^{\mathrm{e}}$ & 300200150 & 590290 & 345230150 & I & P. sylvestris & Infected wood & Siemianice \\
\hline & $7012^{\mathrm{f}}$ & 300200150 & 590290 & 345230150 & I & P. sylvestris & Fruit body & Siemianice \\
\hline & 7025 & 300200150 & 590290 & 345230150 & I & Soil surface & Fruit body & Siemianice \\
\hline & $6029 g$ & 300200150 & 590290 & 345230150 & II & P. sylvestris & Infected wood & Zielonka \\
\hline & $\underline{6034^{\mathrm{h}}}$ & 300200150 & 590290 & 345230150 & II & P. sylvestris & Infected wood & Złotów \\
\hline & $\overline{6111^{i}}$ & 300200150 & 590290 & 345230150 & II & P. sylvestris & Infected wood & Siemianice \\
\hline & 7015 & 300200150 & 590290 & 345230150 & II & P. sylvestris & Fruit body & Siemianice \\
\hline & $\underline{7018^{i}}$ & 300200150 & 590290 & 345230150 & II & P. sylvestris & Fruit body & Złotów \\
\hline & $\underline{6050} \underline{\underline{k}}$ & $400300200150^{3}$ & 590290 & 345230150 & III & P. sylvestris & Infected wood & Złotów \\
\hline & $8023^{1}$ & 400300200150 & 590290 & 345230150 & III & P. sylvestris & Infected wood & Siemianice \\
\hline & 7007 & 300200150 & 590290 & 345230150 & III & P. sylvestris & Fruit body & Zielonka \\
\hline & $\underline{7017}$ & 300200150 & 590290 & 345230150 & III & P. sylvestris & Fruit body & Złotów \\
\hline & $\overline{7040}$ & 300200150 & 590290 & 345230150 & IV & P. sylvestris & Fruit body & Złotów \\
\hline & $\overline{8037}$ & 300200150 & 590290 & 345230150 & IV & P. sylvestris & Infected wood & Złotów \\
\hline
\end{tabular}

Explanation

Identical to: ${ }^{\mathrm{a}}-7028,{ }^{\mathrm{b}}-6002,6004,6005,6007,6008,6012,6014-6017,6019,6021-6023,6105,6106,6108,{ }^{\mathrm{c}}-6024,6107,{ }^{\mathrm{d}}-\underline{6052}-$ $\underline{6055}, \underline{6057}, \underline{6061-6063}, \underline{6065}, \underline{6066}, \underline{6068-6079}, \underline{6081-6092}, \underline{6129-6131}, 7024, \underline{7027}, \underline{7043}, \underline{8034-8036}, \underline{8038}, \underline{8043}, \mathrm{e}-6097-6103$, $6110,6112,6113,6115,7029,7038,8002,8004,8009,8011,8014,8020,8024-8027,{ }^{\mathrm{f}}-7013,7014,7020,7036, \mathrm{~g}-6006,6018$,

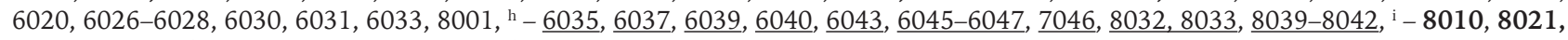
$8022,{ }^{\mathrm{j}}-\underline{7022},{ }^{\mathrm{k}}-\underline{6116}, \underline{6118}, \underline{6119}, \underline{7049},{ }^{1}-6109$

1 - pattern typical for $A$. gallica

2 - pattern typical for A. solidipes according to Harrington and Wingfield (1995)

3 - pattern new for $A$. solidipes

Location of isolates: Number in arial - Siemianice, number in arial bold - Zielonka, number in arial underlined - Złotów

tissue forming at the trunk base or around infected roots, white mycelial mats and rhizomorphs under the bark, clusters of fruit bodies at the base of an infected tree. Thirty-six, 37 and 72 samples of rhizomorphs, fruit bodies and infected wood of Scots pines and sessile oaks (Quercus petraea Mattuschka) were collected at Siemianice, Zielonka and Złotów, respectively. The number of isolates collected was determined by disease severity, which was moderate at Siemianice (10-20\% diseased trees), low at Zielonka (10\%), and high at Złotów (more than 20\%). At each location the previous stand was composed of Scots pine (95-135 years old) with admixture of larch (Larix decidua Mill.), spruce (Picea abies (L.) H. Karst.) and oak (Q. petraea).

At Siemianice and Zielonka the mean annual temperature was $7-9^{\circ} \mathrm{C}$ and at Złotów $6-7^{\circ} \mathrm{C}$, and annual precipitation was $700-800,500$ and $500-600 \mathrm{~mm}$, respectively at the three sites.

Within $12 \mathrm{~h}$ of collection each sample was surface-sterilized in sodium hypochlorite $(7 \%$ active chlorine) for 15-30 s and rinsed three times in ster- ile, demineralized water for $10 \mathrm{~min}$. The pieces were dried between paper towels and placed on $2 \%$ malt extract agar (MEA: Difco malt extract $20 \mathrm{~g} \mathrm{l}^{-1}$, Bacto Agar $15 \mathrm{~g} \mathrm{l}^{-1}$, thiabendazole $230 \mathrm{mg} \mathrm{l}^{-1}$ added in $1 \mathrm{ml}$ concentrated lactic acid, 85-90\%, streptomycin 100 $\mathrm{mg} \mathrm{l}^{-1}$, polymyxin sulphate $50 \mathrm{mg} \mathrm{l}^{-1}$ and sodic benzylpenicillin $100 \mathrm{mg} \mathrm{l}^{-1}$ ) (modified from Legrand and Guillaumin 1993). Cultures were incubated at $25^{\circ} \mathrm{C}$ in darkness and sub-cultured as necessary.

\section{Identification of Armillaria with somatic incompatibility tests}

The Armillaria isolates were initially identified using somatic incompatibility tests following the methods described by Korhonen (1978). Mating tests were performed on $2 \%$ malt yeast extract agar (MYEA: Difco malt extract $20 \mathrm{~g} \mathrm{l}^{-1}$, yeast extract $2 \mathrm{~g} \mathrm{l}^{-1}$, agar $20 \mathrm{~g}$ $\left.\mathrm{1}^{-1}\right)$ in Petri dishes. Each of the unknown 145 isolates was paired with a haploid tester (monospore isolate) of each of five European Armillaria species, i.e. A. borealis, A. cepistipes, A. gallica, A. mellea and A. solidipes 
Table 2. Armillaria testers used for comparison

\begin{tabular}{lllll}
\hline \multicolumn{1}{c}{ No. } & \multicolumn{1}{c}{ Species } & \multicolumn{1}{c}{ Host } & Location & \multicolumn{1}{c}{ Donor } \\
\hline AB99025 & A. borealis & Betula sp. & Finland, Hartola & Korhonen K. $^{\text {a }}$ \\
AC & A. cepistipes & Alnus sp. & Poland, Święciechowa & Korhonen K. $^{\mathrm{a}}$ \\
AG99929 & A. gallica & Juglans regia L. & Poland, topuchówko & Łakomy P. $^{\mathrm{b}}$ \\
AG99060 & A. gallica & Quercus sp. & France, Puy de Dome & Guillaumin J. J. $^{\mathrm{c}}$ \\
AG3 & A. gallica & Corylus avellana L. & France, Paris & Guillaumin J. J. $^{\mathrm{c}}$ \\
AM99033 & A. mellea & Fruit body on the ground & France, Paris & Guillaumin J. J. $^{\mathrm{c}}$ \\
AM7 & A. mellea & Fruit body on the ground & Poland, Zielonka & Łakomy P. \\
AM20051/1 & A. mellea & Betula pendula Roth & Poland, Międzychód & Łakomy P. \\
AO203013 & A. solidipes & Pinus sylvestris L. & & \\
\hline
\end{tabular}

Explanation:

a - Finnish Forest Research Institute, Vantaa, Finland; ${ }^{\mathrm{b}}$ - Department of Forest Pathology, University of Life Science, Poznań, Poland; c - Centre INRA de Clermont Ferrand/ Theix/Lyon, UMR Amélioration et Santé des Plantes, Clermont-Ferrand cedex, France.

(Table 2). After incubation at $25^{\circ} \mathrm{C}$ for 4 weeks in darkness the mating reaction was scored on the basis of the appearance of the mycelium. If the two cultures were confluent, this indicated that the isolates were the same species (the same somatic compatibility group). A gap between the two cultures, with a reaction zone consisting of sparse to absent mycelia (i.e. mutual inhibition) indicated an antagonistic reaction between two genetically distinct isolates. Paired cultures were examined every 7 days until a clear and obvious compatibility or incompatibility reaction was observed. Any pairing that gave ambiguous or intermediate results was repeated.

Somatic incompatibility tests with diploid isolates of Armillaria collected throughout the plots were done to distinguish genetically distinct individuals (genets) within A. solidipes (Shaw and Roth 1976). Mycelial plugs of isolates were placed $4 \mathrm{~mm}$ apart on $2 \%$ MYEA and plates were incubated at $25^{\circ} \mathrm{C}$ for 4 weeks in darkness. Isolates from the same plot were paired in all possible combinations, including self-pairings as controls. Two isolates were identified as belonging to the same somatic compatibility group if they merged to form a single colony (Rizzo and Harrington 1993). A line of demarcation between the cultures indicated somatic incompatibility. Once somatic compatibility groups were identified within plots, pairings were done between isolates from different plots.

\section{DNA Extraction, PCR Amplification, RFLP Analysis and Sequencing}

Representatives of 18 Armillaria groups and Armillaria testers were grown in $2 \%$ malt extract broth (MEB: Difco malt extract $20 \mathrm{~g} \mathrm{l}^{-1}$ ) at $24^{\circ} \mathrm{C}$ for 3 weeks in darkness. The mycelium was harvested with a strainer, lyophilized and ground to a fine powder in liquid nitrogen. DNA was extracted with the BeadBeat Micro Gravity (A\&A Biotechnology, Gdynia, Poland) from $10 \mathrm{mg}$ of powdered mycelium, according to the protocol provided. The ITS rDNA (between the $3^{\prime}$ end of the SSU 18S rDNA and the 5' end of the LSU 28S) and IGS-1 rDNA (between the 3' end of the LSU 28S rDNA and the 5' end of the 5S gene) were amplified respectively with PCR primer pairs: ITS1 (5' TCCGTAGGTGAACCTGCGG 3') and ITS4 (5' TCCTCCGCTTATTGATATGC 3') and CNL12 (5' CTGAACGCCTCTAAGTCAG 3') and 5SA (5' CAGAGTCCTATGGCCGTGGAT 3') (Matsushita and Suzuki 2005; Keča et al. 2006). The translation elongation factor-1 alpha gene (EF-1 alpha gene) was amplified with primers EF595F (5' CGTGACTTCATC AAGAACATG 3') and EF1160R (5' CCGATCTTGTAGACGTCCTG 3') (Maphosa et al. 2006).

Each $25 \mu \mathrm{l}$ PCR mixture included $0.2 \mu \mathrm{M}$ of each primer, 2x PCR MixPlus (Taq DNA polymerase 0.1 $\mathrm{U} \mu \mathrm{l}^{-1}, 4 \mathrm{mM} \mathrm{MgCl}_{2}, 2 \mathrm{mM}$ deoxyribonucleoside triphosphates (dNTPs)) and 100 ng of DNA (A \& A Biotechnology, Poland). For ITS and IGS, PCR conditions included an initial denaturation step at $94^{\circ} \mathrm{C}$ for $5 \mathrm{~min}$ followed by 30 cycles of $94^{\circ} \mathrm{C}$ for $30 \mathrm{~s}, 42^{\circ} \mathrm{C}$ for $1 \mathrm{~min}$, and $72^{\circ} \mathrm{C}$ for $2 \mathrm{~min}$. For EF-1 alpha gene, PCR conditions included an initial denaturation step at $94^{\circ} \mathrm{C}$ for $1 \mathrm{~min}$, then 30 cycles at $94^{\circ} \mathrm{C}$ for $30 \mathrm{~s}$, $53^{\circ} \mathrm{C}$ for $30 \mathrm{~s}$, and $72^{\circ} \mathrm{C}$ for $1 \mathrm{~min}$. These were followed by a final extension of $72^{\circ} \mathrm{C}$ for $10 \mathrm{~min}$ and then cooling to $4^{\circ} \mathrm{C}$. The amplified regions included 600-650 bp (ITS, EF-1 alpha gene) and 800-880 bp (IGS).

The amplified products of the IGS-1 region were subjected to RFLP analysis using restriction enzymes AluI, BsmI and TaqI (MBI Fermentas, St. Leon-Rot, Germany) (Harrington and Wingfield 1995). The PCR reaction mix $(18 \mu \mathrm{l})$ was subjected to digestion by $10 \mathrm{U}$ of enzyme for $12 \mathrm{~h}$ at $37^{\circ} \mathrm{C}($ AluI $), 3 \mathrm{~h}$ at $37^{\circ} \mathrm{C}$ (BsmI) and $3 \mathrm{~h}$ at $65^{\circ} \mathrm{C}(\mathrm{TaqI})$. The products were electrophoresed in gels (2\% NuSieve agarose, Cambrex BioScience, Wokingham, UK $+1 \%$ standard agarose) in $1 \mathrm{x} \mathrm{TBE}$ stained with $0.5 \mu \mathrm{g} \mathrm{ml}^{-1}$ ethidium bromide. Restriction digestion patterns were compared for each enzyme. DNA band sizes were determined by comparison with bands of a $\phi \chi 174$ DNA HaeIII digest and the Low DNA Mass Ladder (Invitrogen Ltd., 
Table 3. Armillaria sequences deposited in NCBI GenBank

\begin{tabular}{lcccc}
\hline \multirow{2}{*}{ Species } & \multirow{2}{*}{ Origin } & ITS 1/2 rDNA & IGS-1 rDNA & EF-1 alpha gene \\
\cline { 3 - 4 } A. borealis & & KF523270 & KM878699 & KM878688 \\
A. cepistipes & tester & KF523271 & KM878700 & KM878687 \\
A. gallica & tester & KF523268 & KM878702 & KM878686 \\
A. gallica & tester & KF523269 & KM878703 & - \\
A. gallica & tester & KF523272 & KM878701 & - \\
A. gallica & tester & KF523265 & KM878696 & KM878689 \\
A. mellea & 7023 & KF523273 & KM878704 & KM878685 \\
A. mellea & tester & KF523274 & KM878705 & KM878684 \\
A. mellea & tester & KF523275 & KM878706 & KM878683 \\
A. solidipes & tester & KF523276 & KM878707 & KM878682 \\
A. solidipes & tester & KF523263 & KM878694 & KM878690 \\
A. solidipes & 6036 - haplotype I & KF523264 & KM878695 & KM878698 \\
A. solidipes & $7015-$ haplotype II & KF523266 & KM878697 & KM878693 \\
A. solidipes & 8023 - haplotype III & KF523267 & & \\
\hline
\end{tabular}

Paisley, UK) using GeneTools gel analysis software (Syngene). Fragments smaller than 100 bp were not scored because they could not be distinguished from primer dimers. Two fragments with difference $<10$ bp were considered identical.

The amplified fragments of rDNA were purified using Clean-Up Kit (A \& A Biotechnology, Gdańsk, Poland). The ITS1/2 rDNA was sequenced with primers ITS1 and M 13 fwd (5' GCCAGGGTTTTCCCAGTCACGA 3'), IGS-1 rDNA with primers CNL12 and 5SA, and EF-1 alpha gene with primers EF595F and EF1160R, at DNA Research Centre (Poznań, Poland), using the BigDye ${ }^{\circledR}$ Terminator $\mathrm{v}$ 3.1 Cycle Sequencing Kit (AB Applied Biosystems, Foster City, CA 94404, USA) and ABI PRISM 3100 Genetic Analyzer (Applied Biosystems, Foster City, USA). Sequences were queried against GenBank database using BLAST. Nucleotide sequences of ITS1/2, IGS-1 rDNA, and EF-1 alpha gene of Armillaria testers and representative isolates were deposited in NCBI GenBank (Table 3).

\section{DNA Sequence Analysis}

ITS1/2, IGS-1 rDNA and EF-1 alpha gene sequences of representative Armillaria isolates and testers were compared. They were automatically aligned and manually adjusted using the program Clustal X version 1.8 (Thompson et al. 1997). The total number of characters included in the alignment for ITS1/2, IGS-1 rDNA and EF-1 alpha gene were respectively 418, 584 and 436. Missing and ambiguous data were excluded from the analysis.

Phylogenetic analysis was performed by the neighbor-joining (NJ), maximum likelihood (ML) and maximum parsimony (MS) methods. Neighbor-joining analysis took as input a distance matrix specifying the distance between each pair of isolates. Maximum likelihood analysis was performed with the Tamura-Nei model using heuristic search procedure (Nearest-Neighbor-Interchange, NNI) with an initial tree generated automatically by applying $\mathrm{NJ}$ and BJONJ algorithms. Maximum parsimony analysis was performed using the heuristic search procedure (Subtree-Pruning-Regrafting; SPR) with the widest search level (level 3) with 10 replications in the Random Additions method for the initial tree. The percentages of replicate trees in which associated taxa clustered as determined by bootstrap analysis (1000 replicates) were indicated at the nodes of the phylogram. Bootstrap support (BS) values $>60 \%$ were considered significant in this study. Evolutionary distances were computed using the maximum composite likelihood method and were expressed as number of base substitutions per site. Phylogenetic analysis was performed using MEGA 5.0 (Tamura et al. 2011). Because NJ, ML and MS trees showed similar topologies (data not shown) only the NJ trees are shown in Figs 2-4. The Schizophyllum commune Fr. sequence was used as an outgroup sequence after Hasegawa et al. (2010).

\section{Statistical analysis}

The coefficients of genetic similarity (S) of the isolates were calculated using the formula of Nei and Li (1979). The data were scored and entered in a computer as binary matrices where 0 coded for absence and 1 for presence of a band formed by RFLP of IGS rDNA. Estimates of similarity were based on the total number of shared fragments. The principal component and the average linkage cluster analyses were performed using the statistical package GenStat v. 7.1.

Measures of haplotype diversity $\left(H_{d}\right)$ were based on the estimated haplotype frequencies in the sample (Nei 1987). Differences among A. solidipes haplotypes were analysed with the total number of polymorphic sites $(S)$, nucleotide diversity per site 
between two sequences ( $\Pi$, Nei 1987) and the average number of pairwise nucleotide differences between two sequences ( $k$, Tajima 1983). Haplotypes were reconstructed using PHASE v. 2.1 (Stephens and Donnelly 2003), as implemented in DNASP v. 5.10 (Librado and Rozas 2009). Sites with gaps were excluded from analyses.

\section{Results}

\section{Isolates}

Thirty-six, 37 and 72 diploid isolates of Armillar$i a$ were obtained from rhizomorphs, fruit bodies and infected wood of Scots pines and sessile oaks from two infection centres in, respectively, Siemianice, Zielonka and Złotów Forest Districts (Table 1).

\section{Identification of Armillaria with somatic incompatibility tests}

In somatic incompatibility tests performed with haploid testers, two isolates were identified as $A$. gallica and 143 as $A$. solidipes. In somatic compatibility tests performed for all within-centre and between-centre pairings, the 143 isolates of $A$. solidipes formed colonies with no dark lines or barrier zones. However, there were different levels of somatic compatibility: completely compatible interaction, intermediate reaction, and partly compatible reaction showing a sparse zone and pigment formation. There were also differences in colony morphology (velvety, crustose, flat, rhizomorphogenic, light or dark brown with age), formation of rhizomorphs, rhizomorphs morphology (compact or open due to intensity of branching, submerged and aerial, cylindrical or flat) and growth rate. On the basis of these differences 18 somatic compatibility groups were distinguished (a-1 + single isolates). Each group was represented by 1-45 isolates. Four groups were from Zielonka (including b, c, g), eight from Złotów (including d, $\mathrm{h}, \mathrm{j}, \mathrm{k}$ ) and six from Siemianice (including e, f, i, l) (Table 1).

\section{PCR Amplification, RFLP and Sequence Analysis}

For 143 isolates, PCR amplification of the ITS1/2 and IGS-1 rDNA yielded single strong bands of 600 $650 \mathrm{bp}$. RFLP patterns of IGS-1 rDNA with AluI, BsmI or TaqI yielded 2-4 fragments of rDNA (Tables 1, 4).

Testers and two A. gallica isolates from Q. petraea (including 7023) gave AluI pattern $=400240180$ (typical for A. gallica) and TaqI pattern $=345200$ 160. Testers and 136 A. solidipes isolates from P. sylvestris gave AluI pattern $=300200$ 150, BsmI pattern
Table 4. RFLP patterns of the IGS-1 rDNA from Armillaria generated with digestion enzymes

\begin{tabular}{cccc}
\hline Species & AluI & BsmI & TaqI \\
\hline A. borealis & 300200130 & & 345240150 \\
& 300200150 & & \\
A. cepistipes & 400200180 & & 345190160 \\
& 300200150 & & \\
A. gallica & 400240180 & & \\
& 400250240180 & & \\
A. mellea & 380230180 & & \\
& 320180150 & & 345230150 \\
A. solidipes & 300150 & & 500190150 \\
& 300200150 & 590290 &
\end{tabular}

$=590290$ and TaqI pattern $=345230150$ (all typical for $A$. solidipes). Two A. solidipes isolates $(6050,8023)$, although having typical $A$. solidipes patterns for BsmI (590 290) and TaqI (345 230 150), gave a new AluI pattern (400 300200 150) which was not recorded by Harrington and Wingfield (1995). The similarity coefficient values for the $143 \mathrm{~A}$. solidipes pairwise genotype combinations $(0.5555-1.0)$ showed genetic similarity between $55.5 \%$ and $100 \%$. Seven isolates had $55.5 \%$ similarity to each other. The other 136 isolates were identical.

Sequencing of ITS1/2 rDNA confirmed the identification of A. gallica (7023). Sequencing of ITS1/2 rDNA from the 18 A. solidipes isolates from 18 somatic compatibility groups delineated four nuclear $A$. solidipes haplotypes (Table 1). The largest haplotype I (represented by isolate 6036) was identical to A. solidipes tester KF523276 and included 99 isolates. Haplotype II (represented by isolate 7015) included 33 isolates. Haplotype III (represented by isolate 8023) included nine isolates, and haplotype IV (represented by isolate 7040) included two isolates. Haplotype III included isolates with two AluI patterns. Isolates within haplotypes were isolated from fruit bodies, rhizomorphs and infected wood from the three locations surveyed, which were located $100-350 \mathrm{~km}$ apart, with no geographical or substrate specialization. In the ITS1/2 rDNA phylogenetic tree, three $A$. solidipes isolates, 6036, 8023 and 7040, representing haplotypes I, III and IV, joined, non-significantly, A. solidipes tester KF523276 (BS 53\%), while isolate 7015, representing haplotype II, joined, non-significantly, A. borealis (BS 44\%) (Fig. 2). This was because of the small amount of nucleotide diversity $(\Pi=0.00012)$; the number of nucleotide substitutions in the $418 \mathrm{nu}$ cleotide base-pair region was 0-2 (Table 5).

Sequencing of IGS-1 rDNA of representative isolates $(6036,7015,7040,8023)$ from four haplotypes did not confirm clearly the identification by sequencing of ITS1/2 rDNA. In the IGS- 1 rDNA phylogenetic trees only isolate, 7015 , joined significantly $A$. solidipes (BS 76\%). The other isolates $(6036,8023$, 7040 ) were significantly included in the $A$. borealis + 
Table 5. Nucleotide polymorphism in ITS 1/2 rDNA sequences of Armillaria

\begin{tabular}{|c|c|c|c|c|c|c|c|c|c|c|}
\hline \multirow{2}{*}{ Species } & \multicolumn{10}{|c|}{ Nucleotide position } \\
\hline & 7 & 78 & 270 & 273 & 296 & 331 & 373 & 408 & 410 & 414 \\
\hline A. borealis tester KF523270 & $\mathrm{C}$ & $\mathrm{C}$ & $\mathrm{C}$ & $\mathrm{C}$ & $\mathrm{C}$ & A & $\mathrm{C}$ & G & A & G \\
\hline A. cepistipes KF523271 & $\mathrm{C}$ & $\mathrm{C}$ & $\mathrm{C}$ & $\mathrm{C}$ & $\mathrm{T}$ & G & $\mathrm{T}$ & - & G & A \\
\hline A. gallica tester KF523268 & $\mathrm{C}$ & $\mathrm{T}$ & $\mathrm{C}$ & $\mathrm{C}$ & $\mathrm{C}$ & G & $\mathrm{T}$ & - & A & A \\
\hline A. gallica tester KF523269 & $\mathrm{C}$ & $\mathrm{C}$ & $\mathrm{C}$ & $\mathrm{C}$ & $\mathrm{C}$ & G & $\mathrm{T}$ & - & A & A \\
\hline A. gallica tester KF523272 & $\mathrm{T}$ & $\mathrm{C}$ & $\mathrm{C}$ & $\mathrm{C}$ & $\mathrm{C}$ & G & $\mathrm{T}$ & - & A & A \\
\hline A. gallica 7023 & $\mathrm{~T}$ & $\mathrm{C}$ & $\mathrm{C}$ & $\mathrm{C}$ & $\mathrm{C}$ & G & $\mathrm{T}$ & - & A & A \\
\hline A. solidipes tester KF523276 & $\mathrm{C}$ & $\mathrm{C}$ & $\mathrm{T}$ & $\mathrm{C}$ & $\mathrm{C}$ & G & $\mathrm{T}$ & G & A & G \\
\hline A. solidipes 6036 - haplotype I & $\mathrm{C}$ & $\mathrm{C}$ & $\mathrm{T}$ & $\mathrm{C}$ & $\mathrm{C}$ & G & $\mathrm{T}$ & G & A & G \\
\hline A. solidipes 7015 - haplotype II & $\mathrm{C}$ & $\mathrm{C}$ & $\mathrm{C}$ & $\mathrm{C}$ & $\mathrm{C}$ & A & $\mathrm{T}$ & G & A & G \\
\hline A. solidipes 8023 - haplotype III & $\mathrm{C}$ & $\mathrm{C}$ & $\mathrm{C}$ & $\mathrm{C}$ & $\mathrm{C}$ & G & $\mathrm{T}$ & G & A & $\mathrm{G}$ \\
\hline A. solidipes 7040 - haplotype IV & $\mathrm{C}$ & $\mathrm{C}$ & C & A & $\mathrm{C}$ & G & $\mathrm{T}$ & G & A & G \\
\hline
\end{tabular}

A. solidipes clade (BS 96\%, Fig. 3). This was because of much greater nucleotide diversity $(\Pi=0.00077)$; the number of nucleotide substitutions in the 584 nucleotide base-pair region was 4-18 (Table 6).

The topology of the phylogenetic trees was similar for ITS1/2 and IGS-1 rDNA. Both contained three major clades, i.e. A. borealis + A. solidipes, A. gallica and A. mellea. The Armillaria cepistipes lineage joined the $A$. gallica clade.

Sequencing of the EF-1 alpha gene of representative isolates $(6036,7015,7040,8023)$ from four haplotypes confirmed clearly the identification by somatic

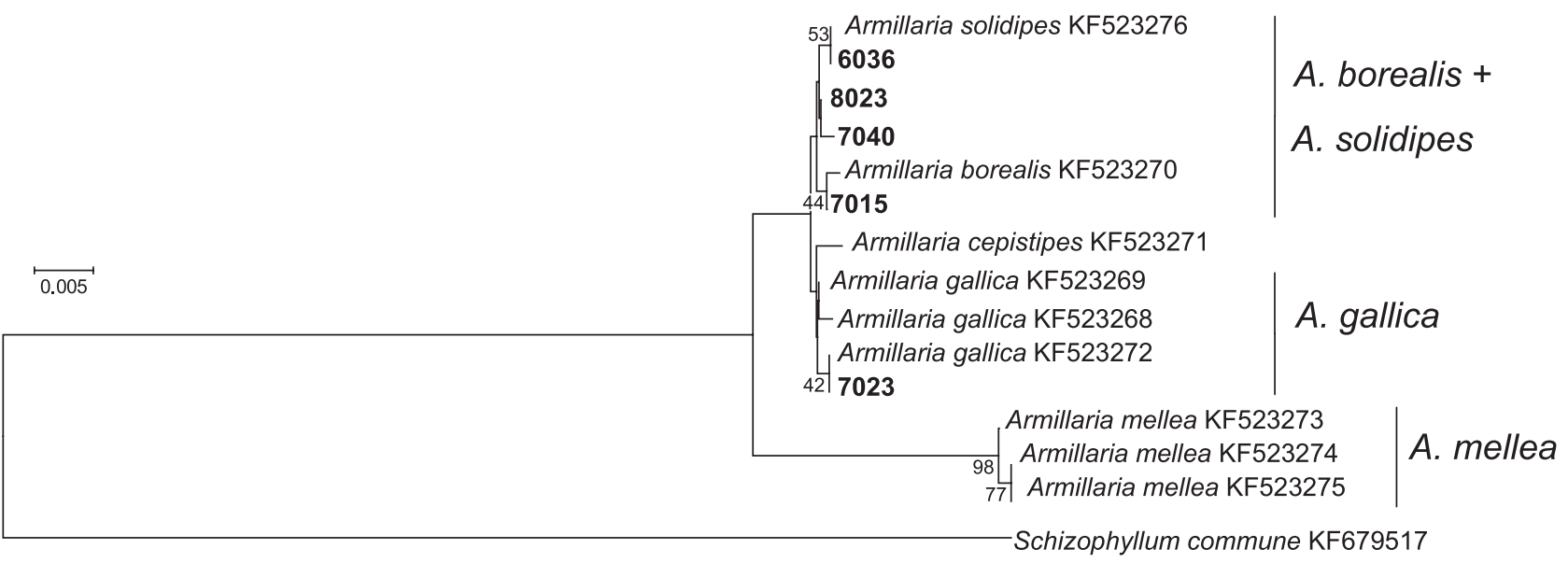

Fig. 2. Phylogenetic tree obtained by neighbor-joining analysis of ITS1/2 rDNA sequences of Armillaria. Gaps and missing data were excluded from the analysis. Bootstrap values (1000 replicates) are listed above the branches. Codes in bold indicate the Polish specimens of Armillaria. Scale bar indicates the percentage of difference between sequences

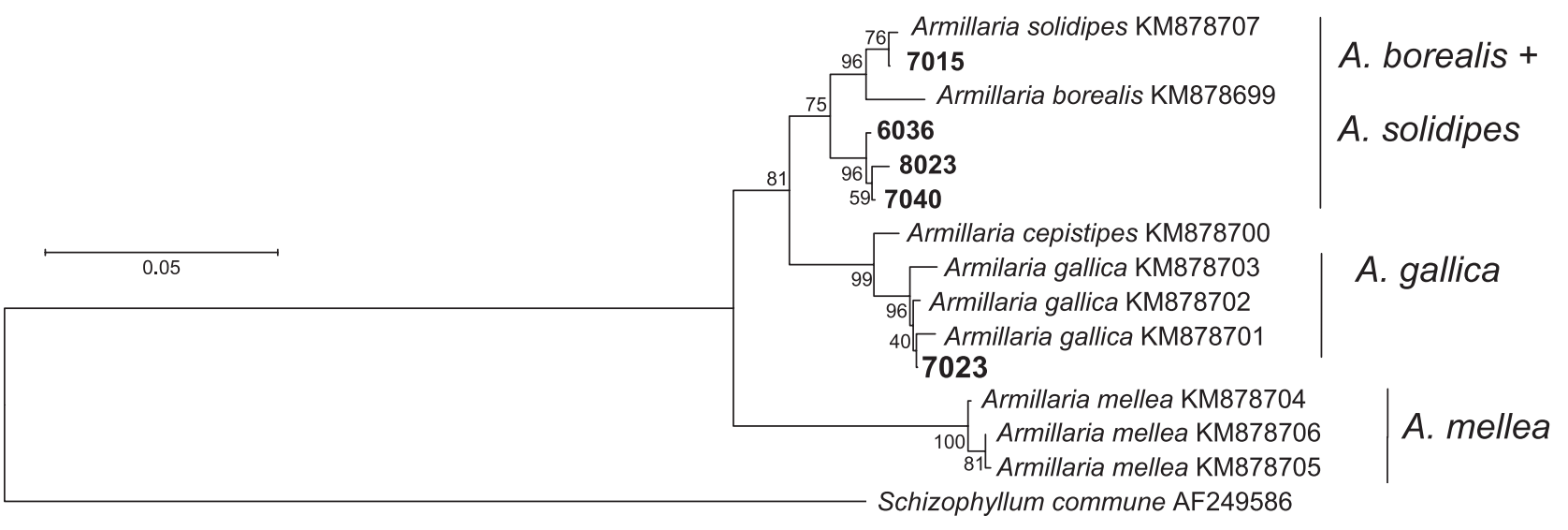

Fig. 3. Phylogenetic tree obtained by neighbor-joining analysis of IGS-1 rDNA sequences of Armillaria. Gaps and missing data were excluded from the analysis. Bootstrap values (1000 replicates) greater than $50 \%$ are listed above the branches. Codes in bold indicate the Polish specimens of Armillaria. Scale bar indicates the percentage of difference between sequences 


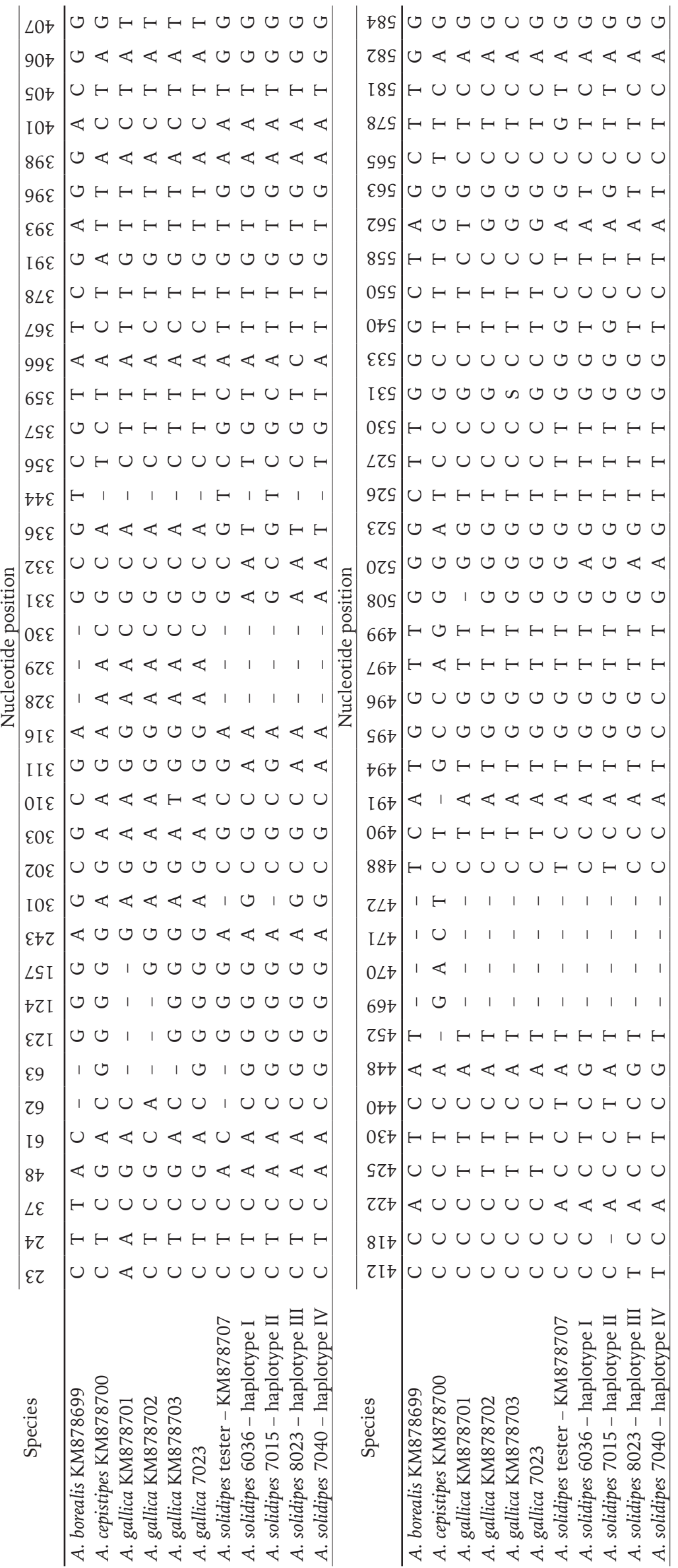




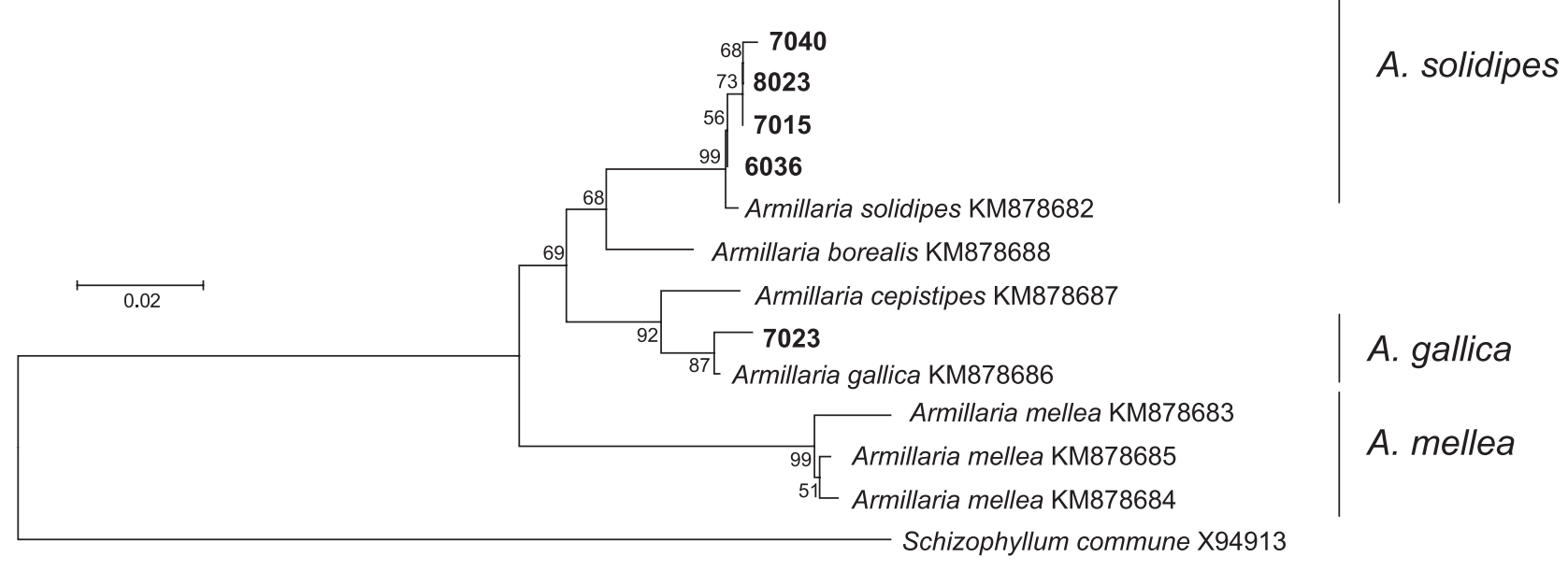

Fig. 4. Phylogenetic tree obtained by neighbor-joining analysis of EF-1 $\alpha$ gene of Armillaria. Gaps and missing data were excluded from the analysis. Bootstrap values (1000 replicates) are listed above the branches. Codes in bold indicate the Polish specimens of Armillaria. Scale bar indicates the percentage of difference between sequences

incompatibility tests. All A. solidipes isolates joined, mostly significantly, A. solidipes tester KM878682 (BS 56-99\%) (Fig. 4). The separation of A. borealis from A. solidipes was significantly supported (BS 68\%). This was because of very little nucleotide diversity $(\Pi=$ $0.00001)$; the number of nucleotide substitutions in the 436 nucleotide base-pair region was 1-2 (Table 7).

Haplotype diversity within A. solidipes was moderate $(H d=0.48239)$. The average nucleotide diversity and the average number of pairwise differences per sequence for four $A$. solidipes haplotypes was higher in IGS- 1 rDNA than in ITS1/2 rDNA and the EF-1 alpha gene (Table 8).

Table 8. Nucleotide diversity for $A$. solidipes haplotypes

\begin{tabular}{lccccc}
\hline \multicolumn{1}{c}{ A. solidipes } & $h$ & $H_{d}$ & $S$ & $\Pi$ & $k$ \\
\hline ITS $1 / 2$ & 4 & 0.48239 & 3 & 0.00012 & 0.75 \\
IGS -1 & 4 & 0.48239 & 21 & 0.00077 & 9.75 \\
EF-1 alpha gene & 4 & 0.48239 & 2 & 0.00001 & 0.50 \\
\hline
\end{tabular}

$h$ - total number of haplotypes

$H_{\text {d }}$ - haplotype diversity

$S$ - total number of polymorphic sites

$\Pi$ - nucleotide diversity per site between two sequences

$k$ - average number of pairwise differences per sequence

\section{Discussion}

The virulence of Armillaria species to trees varies from weakly to strongly pathogenic (Kile et al. 1991). Recognition of the population structure and distribution of Armillaria species is important for evaluation of disease impact and application of management practices aimed at preventing infection. Correct recognition of the most common species in northern European forests, i.e. A. solidipes and A. gallica, is of particular importance because of the differences in their pathogenicity. The first species is the most common and the most pathogenic on conifers in central Europe. The second is an opportunistic pathogen in weakened tree hosts, and is a common and ecologically important saprophytic wood-decay fungus (Źółciak 1991, 1999a,b, 2005, 2007; Mańka 2005).

On the basis of somatic incompatibility tests, only one A. gallica and $18 \mathrm{~A}$. solidipes genets were detected in 5-10 year-old Scots pine plantations located $100-350 \mathrm{~km}$ apart in west-central Poland. Three or four groups of genets and between one and four single-isolate $A$. solidipes genets were detected in an area of 4 ha on each site. This diversity is less than the three and six A. solidipes genets per 1 ha found in North America (Worrall 1994), France (Legrand et al. 1996) or Norway (Prospero 2003). The number of genets detected probably depends on the size of the sampling area but also on the kind of substrate and method of sampling. Worrall (1994) and Prospero (2003) analysed soil and stumps. Legrand et al. (1996) analysed rhizomorphs, fruit bodies and mycelia from stumps. We analysed rhizomorphs, fruit bodies and infected wood. The sampling in our study provided representatives of large-, medium-, and small-sized $A$. solidipes genets. There was, generally, geographical specialization of genets. There were, however, some exceptions; in case of four isolates, i.e. $3 \%,(7024,7029,7038,7036)$ there was no compatibility between morphology and location. No other Armillaria species were recorded although we expected to find A. cepistipes, which is reported as one of the most common Armillaria species in Europe (Legrand et al. 1996; Marxmüller and Holdenrieder 2000). It tends, however, to colonize Norway spruce and fir rather than Scots pine (Prospero 2003; Źółciak 2007).

The ITS1/2 and IGS- 1 rDNA regions and the EF-1 alpha gene were assessed for their value in identification of Polish forest Armillaria species. The first procedure was RFLP analysis of IGS-1 rDNA with 
three enzymes. Since Harrington and Wingfield (1995) first identified band patterns with AluI and BsmI for Armillaria species, this approach has been successfully used for studies of North American, European, South African and Japanese species of Armillaria (Chillalli et al. 1998; Coetzee et al. 2000; Mwenje et al. 2003; Hasegawa et al. 2010). Only two isolates gave the enzyme pattern typical for A. gallica. The majority of our isolates gave a pattern typical for A. solidipes. However, a few A. solidipes isolates gave a new pattern with AluI. This, in diploid isolates of A. solidipes, seems to result from heterozygosity and the existence of variable multicopies in the rDNA array (Pérez-Sierra et al. 1999; Kim et al. 2000; Dunne et al. 2002; Smith-White et al. 2002; Lochman et al. 2004a,b; Schnabel et al. 2005; Keča et al. 2006). Hybrid RFLP patterns of the IGS-1 rDNA region have also been discovered in other Armillaria species (Kim et al. 2006; Antonin et al. 2009).

Sequencing of the ITS1/2 and IGS- $1 \mathrm{rDNA}$ showed small nucleotide diversity $(\Pi=0.00012)$ in ITS1/2 rDNA and much more $(\Pi=0.00077)$ in IGS- 1 rDNA of the isolates of $A$. solidipes (Table 8). However, none of these regions has sufficient resolution for the clear differentiation of $A$. solidipes from $A$. borealis. Sequencing of ITS1/2 rDNA allowed differentiation of four haplotypes within $18 \mathrm{~A}$. solidipes genets. This suggests that many of the $A$. solidipes genets are closely related and were possibly established by sib-related basidiospores. However, only representatives of three haplotypes with nucleotide substitution of $0-2 \mathrm{bp}$ joined the A. solidipes tester (Fig. 2). The representative of the fourth haplotype, despite similar low nucleotide substitution of $2 \mathrm{bp}, 0.3 \%$ nucleotide polymorphism and $99.7 \%$ nucleotide similarity, joined $A$. borealis. The phylogenetic tree obtained by neighbor-joining analysis of IGS-1 rDNA presents a completely different effect: the representative of haplotype II (7015), with nucleotide substitution of $2 \mathrm{bp}$ compared with the $A$. solidipes tester, joined $A$. solidipes, while representatives of three other haplotypes, with nucleotide substitution of 16-19 bp compared with the $A$. solidipes tester, formed a subclade in the $A$. borealis and A. solidipes clade.

The insufficient effectiveness of ITS1/2 rDNA analysis for identification of Armillaria species from forest trees was reported earlier (Chillali et al. 1998b; Potyralska et al. 2002; Keča et al. 2006). Potyralska et al. (2002) found considerable similarity in the ITS1/2 rDNA sequences of Polish isolates of $A$. borealis, A. cepistipes, A. gallica and A. solidipes. Studying European isolates with RFLP, Chillali et al. (1998b) found more than $80 \%$ similarity in the ITS1/2 rDNA of $A$. borealis and $A$. solidipes. However, since ITS1/2 rDNA has been used successfully for differentiation of Northern Hemisphere Armillaria species from Australian and Japanese isolates (Dunne et al. 2009;
Hasegawa et al. 2010), we decided to check its effectiveness again in our studies. A further reason was that the ITS region is the formal fungal barcode and is the primary choice for molecular identification of fungi from a number of sources (Schoch et al. 2012).

The occurrence of four haplotypes of $A$. solidipes, despite low nucleotide diversity in the ITS1/2 rDNA, seems to result from mutation. This is often found in diploid organisms (Buckler 1997). The 5.8S gene sequence is highly conserved but the ITS1 and ITS2 sequences are more variable and may be highly polymorphic (Nilsson et al. 2008). Further, many intergenic spacers may exist as a mosaic of functional elements and inactivated pseudogenes at different stages in sample decay (Degnan et al. 2011).

The phylogenetic trees obtained by neighbor-joining analysis of ITS $1 / 2$ and IGS- 1 rDNA sequences of Armillaria show a high level of similarity between $A$. borealis and A. solidipes (Figs 2, 3). This phenomenon has been found earlier among isolates from Europe (Czech Republic, Montenegro, Poland, Serbia and Slovakia), North America and Japan (Anderson and Stasovski 1992; Keča et al. 2006; Hasegawa et al. 2010). We showed, however, satisfactory effectiveness of IGS-1 rDNA in identification of $A$. cepistipes, A. gallica and A. mellea, which agrees with Keča et al. (2006). The average nucleotide substitution between A. cepistipes and A. gallica of 14.5 bp was, however, more than that (8.7) found by Keča et al. (2006).

The analyses of ITS1/2 and IGS-1 rDNA showed much less diversity in the isolates of $A$. solidipes than was found previously using RAPD analysis, in which 16 distinct multilocus haplotypes were found among 22 A. solidipes isolates from Scots pine plantations in west-central Poland (Szewczyk et al. 2014).

The general geographical specialization of genets detected with somatic incompatibility tests was not supported by sequencing of the ITS1/2 rDNA. The three most common haplotypes were detected in each of three locations with no geographical specialization.

The elongation factor- 1 alpha gene has so far been used rarely for identification of European Armillaria species. Only Antonin et al. (2009) used it for differentiation of $A$. gallica and $A$. cepistipes. Other studies using the EF-1 alpha gene included Armillaria from the northern and southern hemispheres (Maphosa et al. 2006), Japan (Hasegawa et al. 2010) and North America (Brazee et al. 2011, 2012; Ross-Davis et al. 2012). In our studies the EF-1 alpha gene analysis allowed recognition of $A$. solidipes (BS 99\%) and clear separation of $A$. borealis from $A$. solidipes and A. cepistipes from A. gallica (BS 68\% and 92\%, respectively). There was very low nucleotide diversity in the $A$. solidipes EF-1 alpha gene $(\Pi=0.00001)$. Since the EF-1 alpha gene sequence was also found to be the most suitable for identifying different species of Japanese Armillaria (Hasegawa et al. 2010) it seems to 
be the most useful for recognition of forest Armillaria species in the Northern Hemisphere. The EF-1 alpha gene is a highly conserved ubiquitous protein with high resolution necessary for phylogenetic studies of species (Roger et al. 1999) and its usefulness as a phylogenetic marker is confirmed by our studies. One of the obvious benefits of its application is its relatively easy amplification because of its large copy numbers and the possibility of amplification directly from decayed wood, mycelial fans, rhizomorph tissues or fungal cultures without DNA extraction.

The phylogenetic trees constructed with sequence data of the ITS1/2, IGS-1 rDNA and the EF-1 alpha gene were roughly similar in topology. Isolates of $A$. borealis $+A$. solidipes, A. gallica and A. mellea formed independent clades, and the single isolate of $A$. cepistipes had a more or less independent lineage which joined A. gallica clades. Although the overall similarity values differed, trends such as: (i) the similarity of $A$. borealis and $A$. solidipes, and of $A$. cepistipes and $A$. gallica, and (ii) the separation of $A$. mellea, were common to all three trees. Such differentiation is consistent with findings of Korhonen (1995) who, 20 years ago, on the basis of morphological and biological features only, divided northern hemisphere Armillar$i$ a species into three groups: $A$. ostoyae group, which included $A$. borealis and $A$. ostoyae (=A. solidipes); $A$. gallica group, which included $A$. cepistipes and $A$. gallica; and $A$. mellea designated as a single-species group.

Genetic variability is strongly associated with climatic factors such as temperature and precipitation, which affect the frequency and abundance of fructification and sporulation (Straatsma et al. 2001). The scarcity of fruit bodies in dry conditions may inhibit the formation of new genets, favour the existence of old ones and eliminate competition (Worrall 1994; Ferguson et al. 2003; Bendel et al. 2006). Total annual precipitation in west-central Poland over the past 10 years averaged $500-800 \mathrm{~mm}$, with $25-30 \%$ of that total falling in June-October when mild temperatures persist and fungi are most likely to fruit, and so should have stimulated Armillaria sporulation and hence increased the genetic variability. This may have been counterbalanced, however, by (i) the size of the A. solidipes genet which can spread by rhizomorphs on 20-965 ha (Ferguson et al. 2003) and (ii) a high degree of genetic stability of Armillaria established over more than 1500 years (Smith et al. 1992). Geographical specialization detected by somatic incompatibility tests suggest that the population structure of $A$. solidipes in west-central Poland results rather from clonal reproduction (i.e. vegetative, mitotic, from an original initial mycelium, mostly via rhizomorphs or airborne asexual propagules). The dominance of clonal reproduction of Armillaria has also been reported from western United States, eastern England and Australia (Shaw and Roth 1976; Rish- beth 1978; Kile 1983). The molecular analyses show, however, that sexual reproduction, with dispersal and infection via basidiospores, may be more frequent than expected. Domination of single haplotypes (i.e. haplotypes I and II) and the rare occurrence of others in pine plantations in west-central Poland suggest, however, that site-directed conservative gene flow (including intraspecific crossings) dominates over random genetic drift, and supports the theory of genetic structure of the pathogen's population, i.e. that it is typically composed of many different physiological races but with a few dominants (Burdon 1993).

\section{Conclusions}

Armillaria solidipes is the most common Armillar$i a$ in P. sylvestris plantations in west-central Poland. Geographical specialization of genets and the dominance of single haplotypes suggest that its population results from clonal rather than sexual reproduction. The sequences of the EF 1-alpha gene showed high interspecific variability in Armillaria species and very low intraspecific variability in A. solidipes in Poland. This gene is the most appropriate for reliable identification of biological species and subgroups of Armillaria. Its application is the most useful in ecological and epidemiological studies of Armillaria.

\section{Acknowledgements}

This work was supported by the research project from the Polish Ministry of Science and Higher Education (N303 077 31/2642).

\section{References}

Anderson J.B., Stasovski E. 1992. Molecular phylogeny of northern hemisphere species of Armillaria. Mycologia 84: 505-516.

Antonin V., Tomšovský M., Sedlák P., Májek T., Jankovský L. 2009. Morphological and molecular characterization of the Armillaria cepistipes-A. gallica complex in the Czech Republic and Slovakia. Mycological Progress 8: 259-271.

Banik M.T., Volk T.J., Burdsall H.H. 1996. Armillaria species of the Olympic Peninsula of Washington state, including confirmation of North American biological species XI. Mycologia 88: 492-496.

Bendel M., Kienast F., Rigling D. 2006. Genetic population structure of three Armillaria species at the landscape scale: a case study from Swiss Pinus mugo forests. Mycological Research 110: 705-712.

Brazee N.J., Hulvey J.P., Wick R.L. 2011. Evaluation of partial tef1, rpb2 and nLSU sequences for identification of isolates representing Armillaria calves- 
cens and A. gallica from northeastern North America. Fungal Biology 115: 741-749.

Brazee N.J., Ortiz-Santana B., Banik M.T., Lindner D.L. 2012. Armillaria altimontana, a new species from the western interior of North America. Mycologia 104: 1200-1205.

Buckler E.S., Ippolito A., Holtsford T.P. 1997. The evolution of ribosomal DNA: divergent paralogues and phylogenetic implications. Genetics 145: 821-832.

Burdon J.J. 1993. Genetic variation in pathogen populations and its implications for adaptation to host resistance, In: Durability of disease resistance. Jacobs T., Parlevliet J.E. (eds.). Kluwer Academic Publishers, pp. 41-56.

Chillali M., Idder-Ighili H., Guillaumin J.J., Mohammed C., Lung Escarmant B., Botton B. 1998 a. Variation in the ITS and IGS regions of ribosomal DNA among the biological species of European Armillaria. Mycological Research 102: 533-540.

Chillali M., Wipf D., Guillaumin J.J., Mohammed C., Botton B. 1998 b. Delineation on the European Armillaria species based on the sequences of the internal transcribed spacer (ITS) of ribosomal DNA. New Phytologist 138: 553-561.

Coetzee M.P.A., Wingfield B.D., Coutinho T.A., Wingfield M.J. 2000. Identification of the causal agent of Armillaria root rot of Pinus species in South Africa. Mycologia 92: 777-785.

Degnan P.H., Ochman H., Moran N.A. 2011. Sequence conservation and functional constraint on intergenic spacers in reduced genomes of the obligate symbiont Buchnera. PLoS Genetics 7:e1002252. doi: 10.1371/journal.pgen.1002252.

Dettman J.R., van der Kamp B.J. 2001. The population structure of Armillaria ostoyae and Armillaria sinapina in the central interior of British Columbia. Canadian Journal of Botany 79: 600-611.

Dunne C.P., Glen M., Tommerup I.C., Shearer B.L., Hardy G.E.St J. 2002. Sequence variation in the rDNA ITS of Australian Armillaria species and intra-specific variation in A. luteobubalina. Australian Plant Pathology 31: 241-251.

Ferguson B.A., Dreisbach T.A., Parks C.G., Filip G.M., Schmitt C.L. 2003. Coarse-scale population structure of pathogenic Armillaria species in a mixed-conifer forest in the Blue Mountains of northeast Oregon. Canadian Journal of Forest Research 33: 612-623.

Fukuda M., Nakashima E., Hayashi K., Nagasawa E. 2003. Identification of the biological species of Armillaria associated with Wynnea and Entoloma abortivum using PCR-RFLP analysis of the intergenic region (IGR) of ribosomal DNA. Mycological Research 107: 1435-1441.

Guillaumin J.-J., Anderson J.B., Korhonen K. 1991. Life cycle, interfertility and biological species, In:
Armillaria root disease. Shaw C.G. III, Kile G.A. (eds.). USDA Forest Service, Agriculture Handbook No. 691, pp. 10-20.

Guillaumin J.J., Mohammed C., Anselmi N., Courtecuisse R., Gregory S.C., Holdenrieder O., Intini M., Lun B., Marxmüller H., Morrison D., Rishbeth J., Termorshuizen A.J., Tirro A., Vandam B. 1993. Geographical distribution and ecology of the Armillaria species in western Europe. European Journal of Forest Pathology 23: 321-341.

Harrington T.C., Wingfield B.D. 1995. A PCR-based identification method for species of Armillaria. Mycologia 87: 280-288.

Hasegawa E., Ota Y., Hattori T., Kikuchi T. 2010. Sequence-based identification of Japanese Armillaria species using the elongation factor-1 alpha gene. Mycologia 102: 898-910.

Hintikka V. 1973. A note on the polarity of Armillariella mellea. Karstenia 13: 32-39.

Hood I.A., Redfern D.B., Kile G.A. 1991. Armillaria in planted hosts, In: Armillaria root disease. Shaw C.G. III, Kile G.A. (eds.). USDA Forest Service, Agriculture Handbook No. 691: 122-149.

Keča N., Bodles W.J.A., Woodward S., Karadžić D., Bojović S. 2006. Molecular-based identification and phylogeny of Armillaria species from Serbia and Montenegro. Forest Pathology 36: 41-57.

Kile G.A. 1983. Identification of genotypes and the clonal development of Armillaria luteobubalina Watling and Kile in eucalypt forests. Australian Journal of Botany 31: 657-671.

Kile G.A., McDonald G.I., Byler J.W. 1991. Ecology and disease in natural forests, In: Armillaria root disease. Shaw C.G. III, Kile G.A. (eds.). USDA Forest Service, Agriculture Handbook No. 691: 102-121.

Kim M.-S., Klopfenstein N.B., Hanna J.W., McDonald G.I. 2006. Characterization of North American Armillaria species: genetic relationships determined by ribosomal DNA sequences and AFLP markers. Forest Pathology 36: 145-164.

Kim M.-S., Klopfenstein N.B., McDonald G.I., Arumuganathan K., Vidaver A.K. 2000. Characterization of North American Armillaria species by nuclear DNA content and RFLP analysis. Mycologia 92: 874-883.

Korhonen K. 1978. Infertility and clonal size in the Armillariella mellea complex. Karstenia 18: 31-42.

Korhonen K. 1995. Armillaria since Elias Fries. Acta Universitatis Upsaliensis Symbolae Botanicae Upsalienses 30: 153-161.

Legrand P., Guillaumin J.J. 1993. Armillaria species in the forest ecosystems of the Auveragne (Central France). Acta Oecologica 14: 389-403.

Legrand P., Ghahari S., Guillaumin J.-J. 1996. Occurrence of genets of Armillaria spp. in four mountain forests in Central France: the colonization strat- 
egy of Armillaria ostoyae. New Phytologist 133: $321-332$.

Librado P., Rozas J. 2009. DnaSP v5: a software for comprehensive analysis of DNA polymorphism data. Bioinformatics 25: 1451-1452.

Lochman J., Serý O., Jankovský L., Mikes V. $2004 a$. Variations in rDNA ITS of Czech Armillaria species determined by PCR and HPLC. Mycological Research 108: 1153-1161.

Lochman J., Serý O., Mikes V. 2004b. The rapid identification of European Armillaria species from soil samples by nested PCR. FEMS Microbiological Letters 237:105-110.

Lung-Escarmant B., Mohammed C., Dunez J. 1985. Nouvelles methodes de détermination des Armillairés européens: immunologie et electrophorèse en gel de polycrylamide. European Journal of Forest Pathology 15: 278-288.

Małecka M., Rosa-Gruszecka A., Sierota Z., Szmidla H. 2014. Krótkoterminowa prognoza występowania ważniejszych szkodników i chorób infekcyjnych drzew leśnych w Polsce w 2014 roku (Shortterm prognosis of occurrence of the important pests and diseases of trees in Poland in 2013). Instytut Badawczy Leśnictwa, pp, 144-145.

Mańka K. 2005. Fitopatologia leśna. PWRiL, Warszawa.

Maphosa L., Wingfield B.D., Coetzee M.P.A., Mwenje E., Wingfield M.J. 2006. Phylogenetic relationships among Armillaria species inferred from partial elongation factor 1-alpha DNA sequence data. Australian Plant Pathology 35: 513-520.

Marxmüller H., Holdenrieder O. 2000. Morphologie und populationsstruktur der beringten arten von Armillaria mellea s.l. Mycologia Bavarica 4: 9-32.

Matsushita N., Suzuki K. 2005. Identification of Armillaria species in Japan using PCR-RFLP analysis of rDNA intergenic spacer region and comparisons of Armillaria species in the world. Journal of Forest Research 10: 173-179.

Morrison D., Thomson A.J., Chu D., Peet F.G., Sahotat S. 1985. Isozyme patterns of Armillaria intersterility groups occurring in British Columbia. Canadian Journal of Microbiology 31: 651-653.

Morrison D., Williams R., Whitney R.D. 1991. Infection, disease development, diagnosis, and detection, In: Armillaria root disease. Shaw C.G. III, Kile G.A. (eds.). USDA Forest Service, Agriculture Handbook No. 691: 62-75.

Mwenje E., Ride J.P. 1997. The use of pectic enzymes in the characterization of Armillaria isolates from Africa. Plant Pathology 46: 341-354.

Mwenje E., Wingfield B.D., Coetzee M.P.A., Wingfield M.J. 2003. Molecular characterisation of Armillaria species from Zimbabwe. Mycological Research 107: 291-296.
Nei M. 1987. Molecular Evolutionary Genetics. New York, NY: Columbia University Press.

Nei M., Li W.H. 1979. Mathematical model for studying genetic variation in terms of restriction endonucleases. Proceedings of the National Academy of Sciences of the United States of America 76: 5269-5273.

Nilsson R.H., Kritiansson E., Ryberg M., Hallenberg N., Larsson K.H. 2008. Intra-specific ITS variability in the kingdom Fungi as expressed in the international sequences database and its implications for molecular species identification. Evolutionary Bioinformatics 4: 193-201.

Pegler D.N. 2000. Taxonomy, nomenclature and description of Armillaria. In: Armillaria Root Rot: Biology and control of honey fungus, Fox R.T.V. (ed.). Intercept, Andover, Hants., UK, pp. 8193.

Pérez-Sierra A., Whitehead D.S., Whitehead M.P. 1999. Investigation of a PCR-based method for the routine identification of British Armillaria species. Mycological Research 103: 1631-1636.

Pildain M.B., Coetzee M.P.A., Rajchenberg M., Petersen R.H., Wingfield M.J., Wingfield B.D. 2009. Molecular phylogeny of Armillaria from the Patagonian Andes. Mycological Progress 8: 181-194.

Potyralska A., Schmidt O., Moreth U., Łakomy P., Siwecki R. 2002. rDNA-ITS sequence of Armillaria species and a specific primer for A. mellea. Forest Genetics 9: 119-123.

Prospero S. 2003. Ecology of Armillaria cepistipes: population structure, niches, pathogenicity and interactions with Armillaria ostoyae. Diss., Naturwissenschaften ETH Zürich, 1-112.

Rishbeth J. 1978. Infection foci of Armillaria mellea in first-rotation hardwoods. Annals of Botany 42: 1131-1139.

Rishbeth J. 1985. Infection cycle of Armillaria and host response. European Journal of Plant Pathology 15: 332-341.

Rizzo D.M., Harrington T.C. 1993. Delineation and biology of clones of Armillaria ostoyae, A. gemina and $A$. calvescens. Mycologia 85: 164-174.

Roger A.J., Sandblom O., Doolittle W.F., Philippe H. 1999. An evaluation of elongation factor 1 alpha as a phylogenetic marker for eukaryotes. Molecular Biology and Evolution 16: 218-233.

Ross-Davis A.L., Hanna J.W., Kim M.-S., Klopfenstein N.B. 2012. Advances toward DNA-based identification and phylogeny of North American Armillaria species using elongation factor-1 alpha gene. Mycoscience 53:161-165.

Schnabel G., Ash J.S., Bryson P.K. 2005. Identification and characterization of Armillaria tabescens from the southeastern United States. Mycological Research 109: 1208-1222. 
Schoch C.L., Seifert K.A., Huhndorf S., Robert V., Spouge J.L., Levesque C.A., Chen W. 2012. Fungal Barcoding Consortium; Fungal Barcoding Consortium Author List, Nuclear ribosomal internal transcribed spacer (ITS) region as a universal DNA barcode marker for fungi. Proceedings of the National Academy of Sciences of the United States of America 109: 6241-6246.

Sekizaki H., Kuninaga S., Yamamoto M., Asazu S.N., Sawa S., Kojoma M., Yokosawa R., Yoshida N. 2008. Identification of Armillaria nabsnona in Gastrodia tubers. Biological \& Pharmaceutical Bulletin 31: 1410-1414.

Shaw C.G. III, Roth L.F. 1976. Persistence and distribution of a clone of Armillaria mellea in a ponderosa pine forest. Phytopathology 66: 1210-1213.

Smith M.L., Anderson J.B. 1989. Restriction fragment length polymorphisms in mitochondrial DNAs of Armillaria: identification of North American biological species. Mycological Research 93: 247-256.

Smith M.L., Bruhn J.N., Anderson J.B. 1992. The fungus Armillaria bulbosa is among the largest and oldest living organisms. Nature 356: 428-431.

Smith-White J.L., Summerell B.A., Gunn L.V., Rinzin C., Porter C., Burgess L.W. 2002. Molecular detection and differentiation of Australian Armillaria species. Australian Plant Pathology 31: 75-79.

Stephens M., Donnelly P. 2003. A comparison of Bayesian methods for haplotype reconstruction from population genotype data. American Journal of Human Genetics 73: 1162-1169.

Straatsma G., Ayer F., Egli S. 2001. Species richness, abundance and phenology of fungal fruit bodies over 21 years in a Swiss forest plot. Mycological Research 105: 515-523.

Szewczyk W., Kwaśna H., Bocianowski J., BehnkeBorowczyk J., Ratajczak A., Świetlik A. 2014. Diversity of Armillaria ostoyae in Scots pine plantations in Poland. Dendrobiology 72: 125-137.

Szewczyk W., Łakomy P. 2011. The occurrence of Armillaria species in Siemianice Experimental Forest District. Acta Scientiarum Polonorum. Silvarum Colendarum Ratio et Industria Lignaria10: $5-10$.

Szewczyk W., Mańka M. 2002. Z badań nad występowaniem opieńkowej zgnilizny korzeni drzew w młodych drzewostanach sosnowych Nadleśnictwa Zielonka (The occurrence of Armillaria species in young Scots pine in Experimental Forest District Zielonka). Acta Agrobotanica 55: 319-324.

Tajima F. 1983. Evolutionary relationship of DNA sequences in finite populations. Genetics 105: 437-460.
Tamura K., Peterson D., Peterson N., Steche G., Nei M., Kumar S. 2011. MEGA 5: Molecular Evolutionary Genetics Analysis using Likelihood, Distance and Parsimony methods. Molecular Biology and Evolution 28: 2731-2739.

Terashima K., Cha J.Y., Yajima T., Igarashi T., Miura K. 1998a. Phylogenetic analysis of Japanese Armillar$i a$ based on the intergenic spacer (IGS) sequences of their ribosomal DNA. European Journal Forest Pathology 28: 11-19.

Terashima K., Kawashima Y., Cha J.Y., Miura K. 1998 b. Identification of Armillaria species from Hokkaido by analysis of the intergenic spacer (IGS) region of ribosomal DNA using PCR-RFLP. Mycoscience 39: 179-183.

Thompson J.D., Gibson T.J., Plewniak F., Jeanmougin F., Higgins D.G. 1997. The Clustal X windows interface: flexible strategies for multiple sequence alignment aided by quality analysis tools. Nucleic Acids Research 25: 4876-4882.

Volk T.J., Burdsall H.H. Jr. 1995. A nomenclatural study of Armillaria and Armillariella species (Basidiomycotina, Tricholomataceae). Fungi Flora A/S: Synopsis Fungorum 8: Oslo, Norway.

Wingfield B.D., Maphosa L., Coetzee M.P.A., Mwenje E., Wingfield M.J. 2009. Characterisation of Zimbabwean Armillaria using IGS-1 sequences and AFLP analysis. Fungal Diversity 34: 187-196.

Worrall J.J. 1994. Population structure of Armillaria species in several forest types. Mycologia 86: 401-407.

Żółciak A. 1991. Zmienność wewnątrzgatunkowa grzybów z rodzaju Armillaria - identyfikacja polskich izolatów z rodzaju Armillaria. (Interspecific variability of fungi from Armillaria genus - identification of the Polish isolates from Armillaria). Sylwan 11: 27-40.

Żółciak A. 1999a. Identyfikacja gatunków grzybów z rodzaju Armillaria (Fr.:Fr.) Staude w Polsce. (Identification of species in Armillaria (Fr.:Fr.) Staude genus in Poland). Prace Instytutu Badawczego Leśnictwa Ser. A 888: 3-19.

Żółciak A. 1999b. Występowanie grzybów z rodzaju Armillaria (Fr.:Fr.) Staude w kompleksach leśnych w Polsce. (The occurrence of species from the Armillaria (Fr.: Fr.) Staude genus in forests in Poland). Prace Instytutu Badawczego Leśnictwa Ser. A 890: 29-40.

Żółciak A. 2005. Opieńki (Armillaria spp.). Centrum Informacyjne Lasów Państwowych, Warszawa.

Żółciak A. 2007. Armillaria species in coniferous stands. Acta Mycologica 42: 211-217. 